Comparative Philosophy Volume 12, No. 1 (2021): 98-110

Open Access / ISSN 2151-6014 / www.comparativephilosophy.org

https://doi.org/10.31979/2151-6014(2021).120109

\title{
THE CONCEPT OF NON-DUALITY IN ŚANKARA AND CUSANUS
}

\author{
JEROME KLOTZ
}

\begin{abstract}
When comparing diverse philosophical traditions, it becomes necessary to establish a common point of departure. This paper offers a comparative analysis of Advaita Vedanta Hinduism and esoteric Christianity, as represented by the two highly celebrated figures of Śankara and Nicholas Cusanus, respectively. The common point of departure on which I base this comparison is the concept of "non-duality"- a concept that is fitting for at least two reasons. First, it is general enough to encompass both traditions, pervading the work of each figure, and thus allowing for a kind of "shared language." Second, it is specific enough to identify a set of core and well-defined principles amenable to systematic study, chief among which are the notions of (1) the "Absolute" as an infinite unity that transcends all determinations ("no-thing") and exceeds all oppositions ("not-other"), and (2) the world as an ontologically ambiguous "reflection" that simultaneously hides and manifests its metaontological Principle. In drawing these connections, I hope to show how the concept of nonduality provides the possibility for a mutual understanding among diverse traditions at the philosophical level.
\end{abstract}

Keywords: Advaita Vedānta, metaphysics, mysticism, Nicholas Cusanus, non-duality, Śañkara

\section{INTRODUCTION}

The concept of "non-duality" is not the exclusive possession of any one philosophical system. On the contrary, it can be found-mutatis mutandis-within religiophilosophical traditions the world over: from Philosophical Daoism, Mahāyāna Buddhism, and Advaita Vedānta Hinduism in the East, to Kabbalistic Judaism, esoteric Christianity, and mystical Islam in the West. As such, the concept of non-duality provides a common point of departure by which these traditions, despite their diverse and often disparate outlooks, might pursue a meaningful dialogue and, it is hoped, realize a degree of mutual understanding at the philosophical level (Izutsu 1983, 469).

KLOTZ, JEROME: PhD Candidate, University of Nottingham, UK. Email: Jerome.klotz@nottingham.ac.uk 
To that end, I propose to comparatively analyze the concept of non-duality as set forth in the works of the two highly celebrated figures of Śankara (c. $8^{\text {th }}$ century C.E.) and Nicholas Cusanus (1401-1464 C.E.), representing the Advaitic and Christianesoteric formulations of non-duality, respectively. In doing so, I aim to demonstrate how the speculative insights of both figures, the estrangement of their historico-cultural settings notwithstanding, bear a remarkable affinity in their notions of (1) the "Absolute"-Śankkara's Brahman and Cusanus's Deus - as an infinite unity that transcends all determinations ("no-thing") and exceeds all oppositions ("not-other"), and (2) the world as an ontologically ambiguous "reflection" or "shadow" that simultaneously hides and manifests its meta-ontological Principle.

\section{THE CONCEPT OF NON-DUALITY}

Before delving into a comparative analysis of these figures, I must first clarify what I mean by the term "non-duality." Succinctly stated, "non-duality" refers to the transcendental "unity of opposites" (coincidentia oppositorum). According to non-dual traditions, there are not two different realities: an Absolute Reality "up there," and a relative reality "down here." Rather, the Absolute is the "One without a second." It alone is. Everything "else" is said "to be" only in a relative, dependent, and participatory way. The world has no reality of its own. It is therefore, when viewed from the standpoint of its own internal resources, what the mystics of various traditions analogously refer to as an "illusion" (Śankkara), a "strange amorphousness" (Zhuang Zi), a "total reliance" (Dōgen), a "mixed darkness" (Cordovero), and even a sheer "nothing" (Meister Eckhart and Ibn 'Arabī).

This view poses a direct challenge to the so-called "common-sense" notion of reality. In our ordinary, everyday way of thinking, to say that a flower is "red" and to say that a flower "exists" are two structurally identical statements. The predicates of "redness" and "existence" are here both construed as merely accidental to the "essence" or "quiddity" of which they are predicated, namely, that of a "flower." The non-dual perspective subverts this understanding with what amounts to nothing less than a metaphysical revolution: it is not, strictly speaking, the flower that exists, but existence that "flowers" - "here" in one way (e.g., a rose), and "there" in another (e.g., a lily, a crocus, an orchid, etc.) (Izutsu 1980, 290). Everything is a total dynamic manifestation of the Real, and therefore ontologically ambiguous. On the one hand, the world is rightly spoken of as a "shadow," a "dream," or an "illusion," in that there "is" nothing but the One Real. On the other hand, however, the world is also said "to exist" in the same way that a wave is said "to be" the ocean, or a ray of light is said "to be" the sun (Mukhyananda 1987/2015,101). Accordingly, all phenomena "are" only as the discrete manifestations of a single meta-ontological Principle or "Field": the Oneness that is two-less.

Non-dual "oneness" is therefore not a mathematical but a metaphysical concept. It is not "one" in contrast to the "many"; nor is it "one" as the sum of all parts. Transcending every determination and exceeding every opposition, it is "neither this nor that" (neti, neti), and thus irreducible to the status of any "thing." Paradoxically, 
however, what most differentiates the "one" from all things is its total indistinction from them, i.e., its "not-otherness." More than a merely negative concept, then, nonduality is interpreted as a plenitudinous "void" or super-abounding "abyss," negating every negation, and transcending even transcendence.

The metaphysics of Mahāyāna Buddhism speaks of this non-dual Reality in terms of "emptiness" (śünyatā); a boundless circle with no "inside" or "outside"; an infinite field where "there is not an inch of grass growing." Philosophical Daoism compares it to an "Uncarved Block" ( $p u),{ }^{1}$ a sheer ipseity absolved of all forms, names, distinctions, qualities, and relations: "The dao that can be told is not the Eternal Dao."2 Similarly, the Kabbalistic tradition within Judaism refers to non-dual Reality by the name of Ein Sof (lit. "endless"), a Reality that "is all one and the same," and "nothing is separate from it" (Matt 1996, 27) —what Islamic mysticism designates as the "oneness of existence" (wahdat al-wujūd).

The concept of non-duality therefore cannot simply be written off as just one more philosophically refined way of saying "God." After all, the idea of Divinity implies relationality of one kind or another (e.g., Creator-creature, Lord-servant, Worshippedworshipper, etc.). One might even go so far as to say that, taken at its purest level of analysis, the concept of non-duality has nothing at all to do with "God." As Eckhart could say, non-dual oneness is the "stage" of existence at which every possible distinction has been "broken through," and therefore at which even "God passes away" (Pfeiffer 1857, 181). Yet to call the concept of non-duality "a-theistic" would be no less of a misnomer. Trans-theistic would be the better term, in that the proper notion of non-dual oneness is the reconciliation and mutual indwelling of all contraries and contradictions in a unity so unconditional that it transcends even the condition of being unconditioned (Abe 1995, 146).

None of this is to suggest that the concept of non-duality is the same in all traditions, however. Just the opposite. Non-duality plays a vastly different role in Eastern and Western thought. In Daoist, Mahāyānic, and Advaitic traditions, for example, the concept of non-duality functions on analogy to the sun. It is the shining center of everything - that in the light of which everything else becomes known. ${ }^{3}$ The role of non-duality in Western traditions, by contrast, is more analogous to the way sudden, sporadic flashes of lightning flicker in a dark sky, appearing "out of nowhere," it would seem, and vanishing just as quickly. Or to shift analogies: the concept of non-duality in the West is comparable to "a seed which, however often sown, has never found fertile soil" (Loy 2019, xvii).

This is especially the case with respect to modern Western thought. It is no mere coincidence that the standard genealogy of modern Western philosophy begins with Descartes and his premise of a bifurcated cosmos composed of two realities: (1) "thinking reality" (res cogitans), and (2) "extended reality" (res extensa). From this premise, itself rooted in the nominalist and skeptical philosophies of previous centuries,

${ }^{1}$ Dao-De-Jing, Ch. 32.

${ }^{2}$ Dao-De-Jing, Ch. 1.

${ }^{3}$ Muṇụaka Upanișad, I.i.3 
there arose a kind of ontological "split-vision" through which the dichotomies of subject and object, knower and known, self and other were effectively absolutized and the thread of their intelligible connection severed (Dupré 2008, 11).

It is this bifurcated view of the world which, more than any other, has come to characterize the modern mindset — which, due to globalization, is now as much an Eastern as a Western affair. The peculiar "ontology" that this mindset has tended to harbor, even if it should deny entertaining or privileging any philosophical system whatsoever, goes by the name of "essentialism," the driving logic of which assumes the universal applicability of the laws of identity and non-contradiction, i.e., that $A$ is $A$ and therefore cannot be non- $A$; that $B$ is $B$ and therefore cannot be non- $B$; etc. Here $A$ and $B$ are conceived as two discrete "things" or "substances" that exist independently of each other and relate, if at all, in a merely post hoc, tangential way.

The consequences of this perspective have been both remarkable and devastating. It cannot be doubted that the restriction of "knowledge" (scientia) to that which can be quantifiably analyzed has led to monumental discoveries and advancements in the realms of medicine, technology, and industry. No less undoubtable, however, is the fact that this very same restriction has produced a certain "blindness" to the holistic quality of things, such that modern humanity has become seemingly incapable of recognizing "landscapes as wholes, let alone as the homes of people and other creatures", and instead as little more than the fragmented "sources of extractable products" (Berry, $2015,6)$. This predatory stance vis-à-vis the phenomenal order has been inclined to construe nature as a "thing" or "object" to be conquered, put on the rack and tortured for her secrets, with precious few-if any-objectives beyond those of technological efficiency and "economic yield" (Ellul 1964, 15).

Against these bifurcating and reductivist tendencies, the concept of non-duality seeks to reintegrate all forms of being and knowledge, humanity and nature, within the undifferentiated field of what the late Kitarō Nishida (1870-1945), following Cusanus, had termed their "contradictory identity" (mujunteki dōitsu) (Nishida, 1987, 103), attained through the immediate, intuitive grasp of Reality "prior"-metaphysically speaking - to its having become bifurcated into the categories of subject and object, knower and known, self and other (Alston 1980/2004, 6). For the Zen Buddhist, this Reality is known as "the face all things had before their fathers and mothers were born." For the Sufi, it is conceived as one's "original nature" (fitrah). And for the Advaitin, it is experienced as the realization of the great Upanișadic pronouncement (mahāvākyam) — what Max Müller had called "the boldest and truest synthesis in the whole history of philosophy": "Thou art that" (tat tvam asi) (Müller 1919, 122).

Having briefly clarified my use of the term "non-duality," I turn now to a comparative analysis of Śankara and Cusanus, and the non-dual traditions they represent.

\section{3. ŚAṄKARA AND ADVAITA VEDĀNTA HINDUISM}

The Advaitic understanding of existence (sat) is that of a pure, non-dual unity. This unity or "oneness" (advayatā) is not mathematical but metaphysical in kind 
(Mahadevan 1938/1999, 99). Existence is not a thing to be counted. Perfectly simple, it is without parts. Perfectly infinite, it is beyond enumeration. As a pure, homogenous plenum (bhüma) , existence is beyond all division and diminishment, such that to it, nothing can be added, and from it, nothing can be taken away. Sat is therefore not "one" in contrast to "the many," nor a "whole" in relation to its "parts," but an infinite unity, a seamless simplicity, where nothing is different from anything else: "O One of infinite forms!"4

In the philosophy of Śankara, the concept of non-duality functions as a method of identifying Brahman as the existentiating act and metaphysical substratum of all existents, the super-essential "mode" which, simply by virtue of being what it is, makes all things to be what they are (Pande 1994, 247). As such, existence or sat is not a thing among other things or an object in relation to other objects. "Neither this nor that" (neti, $n e t i$ ) it is the "one without a second" (ekam eva advitīyam). Put another way: the nondual oneness of Brahman transcends all determinations ("no-thing") and exceeds all oppositions ("not-other").

The fundamental claim of Advaitic ontology is that only Brahman is "really real" (satyasya satyam). It alone is void of every difference (viśeșa), quality (guna),

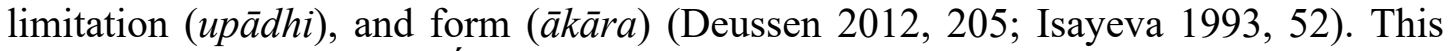
claim is maintained by Śankara through the distinction-often misunderstoodbetween Brahman "with attributes" (saguna) and Brahman "without attributes" (nirguna), a distinction otherwise referred to as "lower" (apara) and "higher" (para) Brahman. To grasp this distinction, it is essential to acknowledge that, for Sankara, there are not two absolutes, one ineffable and the other nameable, one higher and the other lower. Both refer to the same exact reality, albeit as perceived from two radically different standpoints or levels of consciousness: (1) the phenomenal (saprapañca) and (2) the transcendental (nisprapañca). It is in this way that pure existence (sat), though one in itself, is grasped under the two opposed aspects (dvirüpa) of its transcendence ("no-thingness") and immanence ("not-otherness").

To the "lower" Brahman applies the manifold predications of attributes, names, and forms. This is the personal God or Iśvara whose existence is inseparable from the phenomenal order and of whom one may speak as the causative Principle of all things. This causative Principle or Creator-Deity is said to have "produced" or "emanated" the world from Itself as a fire emits its sparks, a spider weaves its web, or a flute produces its music. The manifold of phenomena is, from this perspective, no miscellany of arbitrary inventions that a "divine being" has fashioned "out of nothing" (as in some interpretations of the Judeo-Christian doctrine of creatio ex nihilo), but the many manifestations of oneness itself (advayatā). It is in this way that all "ontophany" (the manifestation of existence) is seen as "henophany" (the manifestation of oneness).

To the "higher" Brahman, by contrast with the "lower," no attribute, name, or form applies. As Śankara says, to "the transcendental Brahman, beyond all conditions, there

${ }^{4}$ Bhagavad-Gìtā, Ch. 11, v. 38. 
can be no such ascription." The "really real" or "absolutely absolute" is "beyond all concepts and all words," such that even those negative or apophatic attributions like invisibility, immutability, and so forth are all infinitely surpassed. Or as Śankara writes elsewhere, "Words with the mind turn back without reaching It as It is without qualities, without actions and without attributes."6

This denial of all names and forms to non-dual existence must not be understood in a merely negative way, however. The absolute manifests itself at every grade of relativity without forfeiting its limitlessness, and that because it has no dialectical relation to it. Finitude, far from something "other" than the infinite, is the latter's contracted expression, just as form (rüpa) is the limited expression of the formless (arüpa). Śankara thus regards the most profound statements of the Upanișads to have for their primary concern not a personal Creator-Deity or transcendent Being of endless qualities (saguna Brahman), but absolute and unqualified existence as such (nirguna Brahman), i.e., "the impersonal (or super-personal) ground in and through which manifestation takes place, itself bereft of all finite characteristics" (Alston 1980/2004, 5). Or as Toshihiko Izutsu summarizes the philosophical vision of Śankara:

...the Absolute which is indicated by the word Brahman is conceived as pure being or "existence" (Sat) - all-pervasive, non-temporal, non-spatial, absolutely unqualified and unlimited-which all so-called "things" are considered so many determinations and particularizations of this absolute Indeterminate... whenever we perceive something in this world we are in reality perceiving Brahman itself, not in its absolute aspect, to be sure, but in one of its particular phenomenal forms (Izutsu 1991, 39, 44).

This, in turn, begs an important question: how can the non-dual absolute remain itself throughout the varied stages of manifold relativity? If, as the famous phrase ascribed to Śankara puts it, "the world is an unbroken series of intuitions of Brahman", then how can the world at the same time be "in all respects nothing but Brahman"?? Here it must be said that just as the saguna Brahman is not a reality "in addition to" the nirguna Brahman, so also the latter does not in any way "become" or "change into" the former. The absolute qua absolute remains eternally unaltered and unalterable. It is itself forever. Brahman does not "become" İ́vara. On the contrary, Íśvara is Brahman, though as viewed from the plane of phenomenal perception (saprapañca). What is more, the ineffable, non-dual oneness of the absolute abides undiminished throughout the descending degrees of its manifestation, from the pure act of existence (sat) down to the pure possibility of prakrti (the material principle of nature, corresponding to the Aristotelian notion of hyle or materia prima).

It is only at this level of parabrahmanic oneness that phenomena can be seen for what they "are": not so many insular "essences" or independent ontological "units" all

\footnotetext{
${ }^{5}$ In Eight Upaniṣads: With the Commentary of Śankarācārya, 2 vols., trans. Swāmī Gambhīrānanda, Kolkata, Advaita Ashrama 1957/2018, 1:385.

${ }^{6}$ Upadeśa Sāhasrī (“A Thousand Teachings"), trans. Swāmi Jagadānanda, Mylapore, Sri Ramakrishna Math Printing Press, 1941/2018, Ch. 15, v. 31.

${ }^{7}$ Vivekacūdāmaṇi ("Crest-Jewel of Discrimination”), §521.
} 
neatly cordoned off from each other, but the mutually interpenetrating modes of nondual oneness, each indwelling all and all indwelling each. As Alston writes:

All is one, and that one an eternal mass of homogenous light. But as one fire breaks up into many sparks without losing its unity, so does the one Self (atman) of all assume the form of the objects of the world and enter into living beings as their "living soul" without forfeiting its essential unity $(2004,5)$.

Śankara accordingly speaks of Brahman as the Self (ätman) who abides at the "heart" or "viscera" (áśaya) of all beings (bhütānāim). Brahman is the beginning (ädi), the middle (madhyam), and the end (antah) of the universe. As the inner sense or meaning of all things, Brahman is the Self that is "to be meditated on, always." 8 Every phenomenal encounter is therefore an encounter with the trans-phenomenal Brahman, just as to be splashed with a wave is the same as being splashed by the ocean, or to bask in a ray of light is the same as basking in the sun itself: "Of the luminaries that illumine, I am the radiant sun."9

As the causative principle of manifestation, Brahman is "the seed of all beings" (sarvabhütānāim bijjaim) and "the Self of all", such that whatever is without Brahman is "null and void." 10 This brings us to what is undoubtedly one of the key concepts of Śankara's entire philosophy: $m \bar{a} y \bar{a}$. While commonly translated as "illusion" and dismissed as acosmic or nihilistic, $m \bar{a} y \bar{a}$ is of a far more nuanced significance, having not only a negative, but a positive aspect as well.

Negatively, māy $\bar{a}$ hides Brahman like a veil hides a face or fog hides a path. Understood in this way, the world is a dream spun of dreams, or a shadow woven of shadows, all of which deceive us into thinking that they are ultimately real. This accords with the so-called "common-sense" notion of what it means to "exist." From the perspective of the lower, relative levels of sat, we speak of what is "real" indiscriminately. We point and say, for example, that "The stone is real" or that "The tree is real" or that "The river is real," etc. But are they? For the Advaitin, the answer is both yes and no. The stone is the appearance of Brahman as a stone. Or to use one of Śankara's preferred analogies, what looks to be a serpent (but, in actuality, is a rope) cannot be nothing (asat) pure and simple, since what is "nothing" has no look to give. The appearance of the serpent is instead a strictly relative and relational borrowing of existence, i.e., a sheer participation in what is "really real" - the one true Reality in relation to which all "else" is shown to be (ultimately) "false."

Which leads now to the positive aspect of $m \bar{a} y \bar{a}$. Beyond its illusory connotations, $m \bar{a} y \bar{a}$ is also considered to be the theatre of "sacred play" (līla $)$, the cosmic dance of Brahman. "Divine indeed is this illusion of mine." 11 Maya is not only a veil that hides reality. It is also a mirror that reveals it. Whereas the veiling power (ávarana-śakti) of

\footnotetext{
${ }^{8}$ In Śrīmad Bhagavad Gītā Bhāṣya of Śrī Śankkarācārya, translated by A.G. Krishna Warrier, Mylapore, Sri Ramakrishna Math, 1983, Ch. 10, v. 20 (hereafter cited as SBGB).

${ }^{9}$ SBGB, ibid.

${ }^{10}$ SBGB, Ch. 10, vv. 39-40.

${ }^{11}$ Bhagavad-Gītā, Ch. 7, v. 14.
} 
$m \bar{a} y \bar{a}$ serves to obscure the truth (or "realness") of existence, its projecting power (vikșepa-śakti) functions something like the heat that spontaneously irradiates from a fire. It is the saguna Brahman or personal Creator-Deity who wields the power of $m \bar{a} y \bar{a}$ in this way, at once transcendent and immanent, the Oversoul (Paramātman) and Esoteric Ruler (Antaryāmin) of manifestation. "There is nothing in this world which is not lit up by God" (Radhakrishnan 1953/1999, 85).

For Śankara, then, the whole world "reflects" or "shadows forth" these two opposed aspects of the non-dual absolute, such that every phenomenon both hides ("no-thing") and manifests ("not-other") its meta-ontological Principle. For Śankkara, all things "are" only as the contracted expressions of the Infinite (ananta). In themselves, they are nothing - or as Śankara says, "null and void"; but in the Infinite, they are not different from the Infinite, i.e., that which is "beyond all determinations" ("no-thing") and from which "nothing is divorced" ("not-other"). ${ }^{12}$

To summarize, Śankara's use of the concept of non-duality functions as a method by which to identify and delineate the following two principles: (1) the "Absolute" (Brahman) is an infinite unity that transcends all determinations ("no-thing") and exceeds all oppositions ("not-other"), and (2) the world is an ontologically ambiguous

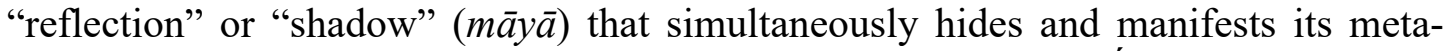
ontological Principle. Having provided the basic outline of Śankara's non-dual philosophy, I turn now to an exposition and comparison of the concept of non-duality as articulated in the work of the outstanding Christian mystic, theologian, and philosopher, Nicholas Cusanus.

\section{NICHOLAS CUSANUS AND ESOTERIC CHRISTIANITY}

Those already acquainted with the writings of Cusanus will know them to be of a "speculative and highly metaphysical character", even a philosophical labyrinth filled with "cryptic and startling utterances" (Hopkins 1980, 8, 12). Despite its daunting quality, however, the German Cardinal's vast oeuvre is not without its controlling concept: non-duality.

The concept of non-duality was first brought to the surface of Christian thought by Pseudo-Dionysius the Areopagite (c. $5^{\text {th }}-6^{\text {th }}$ centuries C.E.) and his Mystical Theology specifically. Cusanus attributed his own notion of God as non-aliud ("not-other") to the intimations of non-duality he had unearthed in the Dionysian corpus:

Dionysius...seems to have come closest to it [i.e., the concept of non-duality]. For in all the things which he expresses in various ways, he elucidates Not-other. But when he comes to the end of his Mystical Theology, he maintains that the Creator is neither anything nameable nor any other thing whatever. Yet, he says this in such a way that he there appears

${ }^{12}$ SBGB, Ch. 11, vv. 40, 42. 
not to be setting forth any important point - although, for one who is attentive, he expressed the secret of Not-other, which secret he everywhere exhibited in one way or another. ${ }^{13}$

At the close of his Mystical Theology, Dionysius had explicitly rejected all affirmations and negations as predicated of the Godhead. For the anonymous monk, human thought and language are rendered impotent before the "dazzling darkness" of the Divine Essence, as the eyes of an owl are overwhelmed by the light of the sun. From it, all speech is put to flight—or, to borrow the phrase of Śankara, "Words with the mind turn back." The non-dual oneness of existence is neither here nor there, neither this nor that, neither dark nor light, neither false nor true. ${ }^{14}$ In that God is absolute, God is not reducible to any one phenomenon or attribute, nor to the whole gamut of phenomena or attributes put together. As Dionysius writes, the Absolute is "beyond the whole" (epekéina tōn holōn). And yet, in that the Absolute is also Infinite, it is not simply other than or different from phenomena either. It was in this way that Cusanus had perceived in the Areopagite a profound elucidation of the concept of non-aliud, if only as an implicit "secret" - one that the "attentive" mind nevertheless discerns "everywhere exhibited in one way or another."

For Cusanus, as for Dionysius, God is the "absolute form" (forma absoluta) of existence. The entire cosmos is therefore viewed as a kind of prolongation or unfolding (explicatio), albeit imperfect, of God-what Dionysius had termed theophania or "manifestation of the Divine" (Perl 2007, 32). The imperfection of the world is due precisely to its being finite, a contracted "reflection" (resplendentia) of the Divine Essence (Hopkins 1980, 38). Insofar as the cosmos is a reflection of the image of Godthe God whom Cusanus, following Dionysius and echoing Śankara, calls the "being of all beings" (omnium esse) ${ }^{15}$ - it reveals the ineffable light of its Principle. Yet, at the very same time, insofar as the cosmos is a reflection of the image of God, it renders that Principle hidden, and for the very reason that it is not itself that Principle. The ontological status of the world is thus, from the Cusanean perspective, fundamentally ambiguous, akin to a luminous shadow (or shadowy luminosity). To that extent, it may be rightly compared to the Vedāntic notion of "illusion" (māya $)$, according to which the world, like a mirage in the desert, "lies." How does it "lie"? By presenting as manifold that which exists in God as a purely undifferentiated unity (complicatio), "a unity which embraces not only the different, but even the opposite, qualities or determinations of being" (Koyré 1957, 8-9).

Cusanus speaks of the unity of existence as both a "coincidence of opposites" (coincidentia oppositorum) and a "coincidence of contradictories" (coincidentiam contradictoriorum). And while these terms might appear, at first glance, to be basically synonymous, a more probing analysis reveals a crucial distinction. The former term

\footnotetext{
${ }^{13}$ De Li Non Aliud, Ch. 1, in Nicholas of Cusa on God as Not-Other: A Translation and an Appraisal of De Li Non Aliud, edited and translated by Jasper Hopkins, $3^{\text {rd }}$ edition (Minneapolis: Arthur J. Banning Press, 1987), 34-37.

${ }^{14}$ Mystical Theology, Bk. 5, 1048A, in Pseudo-Dionysius: The Divine Names and Mystical Theology, edited and translated by John D. Jones (Milwaukee: Marquette University Press), 2015, 222.

${ }^{15}$ De Li Non Aliud, Ch. 14.
} 
embraces the latter without being simply reducible to it, so as to enfold not only contradictories (e.g., non-being and Being) but contraries as well (e.g., motion and rest).

Furthermore, Cusanus never identifies the coincidence of opposites with the Divine Essence Itself. Like the nirguna Brahman of Śankara, the Godhead of Cusanus not only transcends every affirmation, but every possible negation as well. God is, for Cusanus, a "simple oneness" (simplex unitas), a non-dual unity that is "prior-to-all-number" (ante omnem numerum) and "discrete quantity" (quantitate discreta). ${ }^{16}$ What is more, the "simple oneness" of the absolute is - paradoxically - threefold, as represented by the trinitarian formula "Father-Son-Spirit" or "Object-Subject-Union," corresponding to the tertiary formula of the Vedānta: sat-cit-ānanda ("Existence-Knowledge-Bliss").

This trinitarian relation occurs, says Cusanus, "inside the wall of coincidence" (intra murum coincidentiae), "where the distinct and the indistinct coincide" (ubi distinctum et indistinctum coincidunt). ${ }^{17}$ Here Cusanus follows the principle of his fellow German mystic, Meister Eckhart: "everything is in everything." As Bernard McGinn notes, "Eckhart, and after him Nicholas of Cusa, adapted this principle [from Pre-Socratic sources] to describe not only the interpenetration of all things in the universe but also the divine omnipresent transcendence" (McGinn 2001, 169). For Cusanus, non-dual transcendence is the context or setting within which the "coincidence of opposites" occurs and therefore cannot be equated with that coincidence itself. In other words, the coincidentia oppositorum occurs in the Infinite but not as the Infinite. The logic of this move would seem to imply a further (and indeed final) distinction - along the lines of the one drawn by Eckhart and, in a corresponding way, Śankara - between (1) God as the personal, self-giving principle of the cosmos ("God" or aparabrahman), and (2) God as the absolute, trans-personal oneness beyond every possible distinction, attribution, and relation ("Godhead" or parabrahman). It is this "oneness" of which even the Trinity itself is but a reflection, albeit as projected onto the "inner wall of coincidence."

As such, the oneness of the Godhead is not a relative or dialectical oneness. That is to say, it is not a oneness set over against multiplicity and difference. Rather, it is an infinite oneness, perfectly unique ("no-thing") and perfectly universal ("not-other"). As sheer infinity, God is equidistant to every individual point of the universe, in that, like an infinite circle, God's center is everywhere and God's circumference is nowhere. ${ }^{18}$ The non-dual unity of existence is that in which transcendence and immanence "meet," so to speak, not as ontological rivals or competitors, but as the mutually interpenetrating modes of a single, undivided Reality. The Divine Essence, says Cusanus, is neither "here" nor "there," "nor is it this rather than that." 19 It is instead "a mode of unity that

\footnotetext{
${ }^{16}$ Trialogus De Possest, $\S 46$, in A Concise Introduction to the Philosophy of Nicholas of Cusa, edited and translated by Jaspar Hopkins, $2^{\text {nd }}$ edition (Minneapolis: University of Minnesota Press, 1980), 38.

${ }^{17}$ De Visione Dei, Ch. 17, in Nicholas of Cusa's Dialectical Mysticism: Text, Translation, and Interpretive Study of De visione Dei, edited and translated by Jasper Hopkins, $2^{\text {nd }}$ edition (Minneapolis: Banner, 1996), 210-211.

${ }^{18}$ De Docta Ignorantia, Bk. 2, Ch. 12, in Nicholas of Cusa: Selected Spiritual Writings, translated by H. Lawrence Bond (New York: Paulist Press, 1997), 161.

${ }^{19}$ De Doctra Ignorantia, Bk. 3, Ch. 2.
} 
comprises difference without eradicating it" (Casarella 2009, 143). This corresponds to Śankara's view of Brahman as neti, neti and ekam eva advitīyam, the One ("nothing") without a second ("not-other").

The concept of non-duality is thus employed by Cusanus as a "way of viewing and of solving problems from the standpoint of infinity", and in this sense "provides a method that resolves contradictions without violating the integrity of the contrary elements and without diminishing the reality or the force of their contradiction" (Bond, 1997, 22). According to Cusanus, the movement of thought (and theo-logical thinking in particular) proceeds in the shape of a circle (in circulo) ${ }^{20}$ As an infinite circle, God does not view creation as a compromising threat to God's own Self-Reality. God is the boundless center ("no-thing") and circumference ("not-other") of all things, such that to see one is to see the other (Hoff 2013, 166).

For Cusanus, then, as for Śankara, finitude is not, strictly speaking, "other" than the infinite. Just as form (rüpa) is the contracted expression of the formless (arūpa), so creation is a contracted expression of its Creator, and the Creator, in turn, a revelation of non-dual oneness. As such, the world is an icon (eiconam) of shadow and light, and every manifestation of being (ontophany) is convertible with the manifestation of oneness (henophany) - be it a star or a stone, a face or a flower. As the "Absolute Being of all things" (Absolutum esse omnium), God is therefore "the Face of faces" (facies facierum), i.e., the Face that "precedes every formable face and is the Exemplar and Truth of all faces." Every phenomenal "face" is a "contracted shadow-like image" (umbra...contracta), a limited articulation of the Limitless, as waves are the limited articulations of the ocean, or rays of light are the limited articulations of the sun. And just as the brilliance of a ray is not-other-than the sun from which it is derived, so every face that looks to the Absolute "sees nothing other than itself or different from itself, because it sees its own Truth." 21

\section{CONCLUSION}

In this paper I have attempted to comparatively analyze and evaluate the diverse philosophical traditions of Advaita Vedānta Hinduism and esoteric Christianity through their use of the concept of "non-dual oneness," as represented by the figures of Śankara and Cusanus, respectively. Without denying the radical differences and innumerable disparities that obtain between these traditions, I have sought to demonstrate how the speculative insights of Śankara and Cusanus bear a remarkable affinity and philosophical overlap in their notions of (1) the "Absolute" (Brahman; Deus) as an infinite unity that transcends all determinations ("no-thing") and exceeds all oppositions ("not-other"); and (2) the world as an ontologically ambiguous "reflection" or "shadow" (māyā; umbra) that simultaneously hides and manifests its meta-ontological Principle.

\footnotetext{
${ }^{20}$ De Visione Dei, Ch. 3.
}

${ }^{21}$ De Visione Dei, Ch. 6. 
When comparing traditions so diverse, it becomes necessary to establish a common point of departure. It is my contention that the concept of non-duality provides such a "point" in being both (1) specific enough to identify a core set of well-defined principles amenable to systematic study and (2) general enough to permeate the thought-forms of each tradition, thereby allowing for the sort of shared language and structural frame of reference within which meaningful comparisons might be drawn and a mutual understanding more fruitfully developed.

In what is an increasingly pluralistic situation, the need for a mutual understanding among disparate cultures, philosophies, and traditions has become more than a sentimental or pious wish, but an urgent task necessary for the flourishing of human civilizations and the survival of the world we together inhabit.

While such an understanding is pursuable at any number of possible levels, it is the level of philosophy (philosophía, lit. "love of wisdom") which, I contend, ranks among the most promising, if for no other reason than the universality of its impetus and aim. As Aristotle had put it in the opening line of his Metaphysicá: "All people by nature desire to know."22

Reduced to its broadest intention, then, what this paper has sought to demonstrate is how the concept of non-duality epitomizes that "philosophical drive of the human Mind" which, "regardless of ages, places and nations, [is] ultimately and fundamentally one" (Izutsu 1983, 469); and, as such, provides a common - and potentially fertileground for cross-civilizational and interreligious dialogue.

\section{ACKNOWLEDGEMENTS}

A word of gratitude is owed to the anonymous referees of Comparative Philosophy for their constructive comments in revising this article for publication.

\section{REFERENCES}

Abe, Masao (1995), Buddhism and Interfaith Dialogue, ed. Steven Heine (Honolulu: University of Hawaii Press).

Alston, A.J. (1980/2004), Śankara on the Absolute, in A Śankara Sourcebook, 6 vols. ( $2^{\text {nd }}$ ed.) (London: Shanti Sadan).

Berry, Wendell (2015), Our Only World: Ten Essays (Berkeley, CA: Counterpoint).

Bond, H. Lawrence (1997), "Introduction," in Nicholas of Cusa: Selected Spiritual Writings (New York: Paulist Press).

Casarella, Peter (2009), "Cusanus on Dionysius," in Sarah Coakley and Charles M. Stang (eds), Re-Thinking Dionysius the Areopagite (Malden: Blackwell).

Deussen, Paul (1912), The System of the Vedanta, trans. Charles Johnston (Chicago: The Open Court Publishing Co.).

${ }^{22}$ Aristotle, Metaphysics, I.i. 
Dupré, Louis (2008), Religion and the Rise of Modern Culture (Notre Dame, IN: University of Notre Dame Press).

Gambhīrānanda, Swāmī (trans.) (1957/2018), Eight Upaniṣads: With the Commentary of Śañkarācārya, 2 vols. (Kolkata: Advaita Ashrama).

Hoff, Johannes (2013), The Analogical Turn: Rethinking Modernity with Nicholas of Cusa (Grand Rapids: Eerdmans).

Hopkins, Jasper (ed. and trans.) (1987), Nicholas of Cusa on God as Not-Other: A Translation and an Appraisal of De Li Non Aliud ( $3^{\text {rd }}$ ed.) (Minneapolis: Arthur J. Banning Press).

Hopkins, Jasper (ed. and trans.) (1996), Nicholas of Cusa's Dialectical Mysticism: Text, Translation, and Interpretive Study of De visione Dei (2 ${ }^{\text {nd }}$ ed.) (Minneapolis: Banner).

Isayeva, Natalia (1993), Shankara and Indian Philosophy (New York: SUNY).

Izutsu, Toshihiko (1971), "The Basic Structure of Metaphysical Thinking in Islam," in The Concept and Reality of Existence (Tokyo: Keio Institute of Cultural and Linguistic Studies).

Izutsu, Toshihiko (1980), Isurāmu tetsugaku no genzō (Tokyo: Iwanami Shoten).

Izutsu, Toshihiko (1983), Sufism and Taosim: A Comparative Study of Key Philosophical Concepts (Berkeley: University of California Press).

Jagadānanda, Swāmī (1941/2018), Upadeśa Sāhasrī (Mylapore, Sri Ramakrishna Math Printing Press).

Koyré, Alexander (1957), From the Closed World to the Infinite Universe (Baltimore: John Hopkins Press).

Mahadevan, T. M. P. (1938/2006), The Philosophy of Advaita (Delhi: Bharatiya Kala Prakashan).

Matt, Daniel C. (1996), The Essential Kabbalah: The Heart of Jewish Mysticism. (New York: HarperOne).

McGinn, Bernard (2001), The Mystical Thought of Meister Eckhart: The Man From Whom God Hid Nothing (New York: Crossroad).

Mukhyānanda, Swāmī (1987/2015), Sri Shankaracharya: Life and Philosophy: An Elucidative and Reconciliatory Interpretation (Kolkata: Advaita Ashram).

Müller, Max (1919), The Six Systems of Indian Philosophy (London: Longman, Green and Co.).

Nishida, Kitarō (1987), Last Writings: Nothingness and the Religious Worldview, trans. David A. Dilworth (Honolulu: University of Hawaii Press).

Pande, G.C. (1994), Life and Thought of Shankaracharya (Motilal Banarsidass, Delhi).

Perl, Eric D. (2007), Theophany: The Neoplatonic Philosophy of Dionysius the Areopagite (Albany: SUNY).

Pfeiffer (ed.) (1857), Deutsche Mystiker des vierzehnten Jahrhunderts: Meister Eckhart, 2 vols. (Leipzig: G.J. Göshen'sche Verlagshandlung).

Radhakrishnan, Sarvepalli (1953/1999), "Introduction," in The Principle Upanișads (New Dehli: Harper Collins). 